\title{
DFT Simulations of the Structure and Cation Order of Norsethite, $\mathrm{BaMg}\left(\mathrm{CO}_{3}\right)_{2}$
}

\author{
Carlos Pimentel,* Carlos M. Pina, and C. Ignacio Sainz-Díaz
}

Cite This: ACS Earth Space Chem. 2021, 5, 1486-1497

Read Online

ABSTRACT: Norsethite, $\mathrm{BaMg}\left(\mathrm{CO}_{3}\right)_{2}$, is an interesting mineral that can be used to investigate processes leading to the formation of dolomite and other dolomite-type structures. To this end, it is first necessary to study in detail the $\mathrm{Ba}-\mathrm{Mg}$ cation arrangement in the crystal structure of norsethite. In this work, first-principles calculations based on density functional theory (DFT) have been used to simulate cation ordering for the crystal structures of two $\mathrm{BaMg}\left(\mathrm{CO}_{3}\right)_{2}$ polymorphs: the low-temperature polymorph (up to $\sim 360 \mathrm{~K}), \alpha$-norsethite $(R \overline{3} c)$, and the high-temperature polymorph (above $\sim 360 \mathrm{~K}), \beta$-norsethite $(R \overline{3} m)$. We found that for both structural variants of norsethite, the most stable cation arrangements are those with the alternation of barium and magnesium

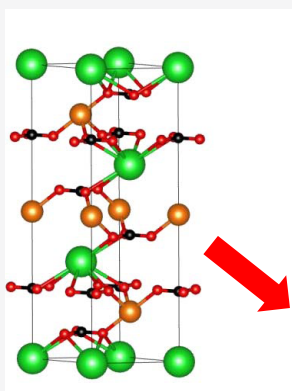

Simulated
Ordered norsethite

energetically more favorable
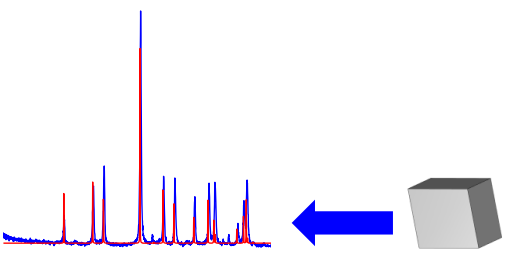

Experimental layers along the $c$-axis. Furthermore, we have adequately simulated nonstoichiometric $\beta$-norsethite structures since some synthetic norsethites were found to have an excess of magnesium, which seems to favor the crystallization of $\beta$-norsethite at room temperature.

KEYWORDS: carbonate, mineral, cation order, dolomite analogue, quantum mechanical simulations, DFT

\section{INTRODUCTION}

Dolomite, $\mathrm{CaMg}\left(\mathrm{CO}_{3}\right)_{2}$, the second most abundant carbonate in the Earth's crust, crystallizes in the $R \overline{3}$ space group (SG) with $Z=3$. Its idealized structure can be described as layers of $\mathrm{CO}_{3}{ }^{2-}$ anionic groups, which separate alternate layers of $\mathrm{Mg}^{2+}$ and $\mathrm{Ca}^{2+}$ along the c-axis of a hexagonal cell. These layers can consist of just one type of cation $\left(\mathrm{Mg}^{2+}\right.$ or $\mathrm{Ca}^{2+}$ ) or, alternatively, each layer can contain a more or less disordered distribution of $\mathrm{Ca}^{2+}$ and $\mathrm{Mg}^{2+}$ cations.

In spite of its abundance and geological relevance, the mechanisms of the formation of dolomite at low temperatures remain elusive. This lack of knowledge is one of the most longstanding and intriguing mineralogical problems, the socalled "dolomite problem", which can be summarized as follows: while dolomite is a very rare mineral in Holocene and modern sediments, it is very abundant in ancient carbonate rocks from Tertiary to Precambrian ages. ${ }^{1}$ Moreover, dolomite cannot be directly synthesized in laboratories at temperatures below $100{ }^{\circ} \mathrm{C}$.

Obviously, to solve the dolomite problem, it is necessary to first understand the mechanisms that lead to an increase in the $\mathrm{Mg}-\mathrm{Ca}$ order within the dolomite structure. Recent studies indicate that the formation of dolomite with a high degree of cation order could require millions of years. For instance, an extrapolation from the results of high-temperature experiments has shown that fully ordered dolomite would require about 6.8 million years to be formed at ambient conditions. ${ }^{2}$ This estimate is in good agreement with those obtained from some isotopic and crystallochemical analyses of natural dolomite samples, ${ }^{3,4}$ which indicate that cation ordering is a slow process that might occur in a geological scale of time.

In the last few decades, cation ordering arrangements in minerals have been studied using atomic computational methods. $^{5-7}$ In particular, recent quantum mechanical and empirical calculations on dolomite nucleation and growth provided new insights into the formation of ordered dolomite. ${ }^{8,9}$ These calculations have shown that while a dolomite bulk structure with a completely ordered cation arrangement is the configuration that is energetically most favorable, the dolomite (10.4) surface is energetically more favorable when $\mathrm{Ca}^{2+}$ and $\mathrm{Mg}^{2+}$ cations are randomly distributed, i.e., when such a surface shows cation disorder., ${ }^{8,9}$ According to Bruno et al., ${ }^{9}$ the cationic order in the dolomite bulk structure would increase progressively by the intracrystalline diffusion process. The sluggishness of such a process at ambient conditions is consistent with dolomite formation times of millions of years.

Received: March 4, 2021

Revised: May 11, 2021

Accepted: May 13, 2021

Published: May 25, 2021

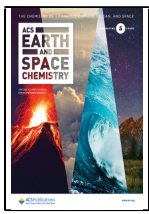


Due to the excessive experimental times required to obtain highly ordered dolomite at ambient conditions, its formation process has been indirectly investigated using two phases with structures close to that of dolomite: Norsethite (BaMg$\left.\left(\mathrm{CO}_{3}\right)_{2}\right)$ and $\mathrm{PbMg}\left(\mathrm{CO}_{3}\right)_{2}{ }^{10-12}$ These phases are called dolomite analogues because their structures can be described as a distorted dolomite structure where calcium cations have been substituted by barium (norsethite) or lead (PbMg$\left.\left(\mathrm{CO}_{3}\right)_{2}\right)$. Due to the larger radii of barium and lead cations, the orientation of carbonate groups differs with respect to that in the dolomite structure. This causes norsethite and $\left(\mathrm{PbMg}\left(\mathrm{CO}_{3}\right)_{2}\right)$ to crystallize into space groups different from the dolomite space group $(R \overline{3})$.

In a first description of the structure of norsethite, the $R 32$ space group was assigned. ${ }^{13}$ However, a further structural refinement concluded that norsethite crystallizes in the $R \overline{3} m$ space group. ${ }^{14}$ Furthermore, recent investigations differentiated between two norsethite structures: $\alpha$-norsethite and $\beta$-norsethite. ${ }^{15,16}$ The $\alpha$-norsethite is a low-temperature polymorph (stable up to $\sim 360 \mathrm{~K}$ ), which crystallizes in the $R \overline{3} c$ SG with $Z=6$, while the $\beta$-structure is a hightemperature polymorph (thermodynamically stable from $\sim 360 \mathrm{~K}$ ), which crystallizes in the $R \overline{3} m$ SG with $Z=3$. $^{16}$

In the last decade, due to the structural similarities of norsethite and dolomite, various researchers considered the norsethite crystallization and properties at ambient conditions as an analogue of dolomite formation. ${ }^{17-27}$ In the experiments reported by Pimentel and Pina, ${ }^{21}$ the formation of norsethite occurred through dissolution-crystallization reactions from precursor phases. Consequently, norsethite showed a progressive increase in the $\mathrm{Ba}-\mathrm{Mg}$ order since its first detection in the crystallization medium. Clearly, to better understand the ordering mechanism that leads to the formation of norsethite through dissolution-crystallization reactions, a detailed description of its structural features for a number of $\mathrm{Ba}-\mathrm{Mg}$ arrangements is fundamental. In addition, the possible formation of metastable structural variants (e.g., $\beta$-norsethite) during the norsethite ordering process must be considered.

In this work, we present quantum mechanical simulations of the structures of $\alpha$-norsethite and $\beta$-norsethite. For the case of $\beta$-norsethite, these simulations were performed for different $\mathrm{Ba}-\mathrm{Mg}$ configurations with different degrees of cation order. We found that the fully ordered alternation of sheets of $\mathrm{Ba}^{2+}$ and $\mathrm{Mg}^{2+}$ cations is the energetically most stable crystal structure of norsethite. Finally, calculated diffractograms from simulated norsethite structures with a number of $\mathrm{Ba}-\mathrm{Mg}$ configurations are compared with the previously reported experimental results.

\section{METHODOLOGY}

The crystal structure, interatomic geometries, and energies were calculated using density functional theory (DFT). All electronic calculations were performed using the CASTEP code implemented in the Material Studio 2019 package (Biovia, Dassault Systems). Generalized gradient approximation (GGA) functional with the Perdew-Burke-Ernzerhof (PBE) parameterization was employed. All calculations were conducted using the Tkatchenko and Scheffler method for dispersion correction, ${ }^{28}$ On-The-Fly-Generated (OTFG) ultrasoft pseudopotentials, relativistic treatment of KoellingHarmon, and an energy cut-off of $630 \mathrm{eV}$ were used. Initially, $\mathrm{rPBE}$ and PBEsol functionals and OTFG norm-conserving pseudopotentials were also tested. The best results were obtained with PBE and ultrasoft pseudopotentials. Therefore, we used the latter conditions for conducting the calculations presented in this work. The convergence gradient for the selfconsistent field (SCF) for energy calculations was $1 \times 10^{-7}$ $\mathrm{eV} /$ atom in the density matrix. The convergence tolerance parameters were set to $5 \times 10^{-6} \mathrm{eV} /$ atom for energy, 0.0001 $\AA$ for maximum displacement, $0.02 \mathrm{GPa}$ for maximum stress, and $0.01 \mathrm{eV} / \AA$ for the maximum force. The structural models were visualized and analyzed using VESTA software. ${ }^{29}$

Single-point energy calculations were used to determine the best energy cut-off to perform the structure optimization. The cut-off values for single-point energy calculations were: 381, $421,461,489.8,520,550,571.4$, and $630 \mathrm{eV}$. The cut-off values were plotted versus the energy calculated (see Figure $\mathrm{S} 1$ ). An energy cut-off of $630 \mathrm{eV}$ was chosen since it is the cut-off value with the least energy variation with respect to the previous cut-off.

The powder X-ray diffraction (XRD) patterns were simulated from the crystal structures using the REFLEX code included in Material Studio 2019 (Biovia, Dassault Systems).

\section{NORSETHITE MODELS}

3.1. General Description of Norsethite Structures. Two different norsethite structures were taken from the literature: the low-temperature polymorph, $\alpha$-norsethite, which crystallizes in the $R \overline{3} c$ space group ${ }^{15}$ and the hightemperature polymorph, $\beta$-norsethite, which crystallizes in the $R \overline{3} m$ space group. ${ }^{14}$ In general terms, both norsethite structures can be described as an alternation of layers of barium cations, carbonate groups, and magnesium cations (Figure 1). However, barium and magnesium positions are not identical. While barium is 12 -fold coordinated, magnesium is 6-fold coordinated. For this reason, cations that occupy a 12 -fold position are labeled as 1 and those that occupy a 6 -fold position are labeled as 2 . The main difference between $\alpha$-norsethite and $\beta$-norsethite structures is related to the arrangement of the oxygen atoms within the carbonate groups. This slight structural difference is enough to modify the symmetry of norsethite by substituting a $c$ glide plane $(\alpha$ norsethite) with a mirror plane ( $\beta$-norsethite). Moreover, this change results in a unit cell of $\alpha$-norsethite, which is twice the length along the c-axis than the unit cell of $\beta$-norsethite. Therefore, in the case of $\alpha$-norsethite, the unit cell contains 12 cationic layers and 12 carbonate layers (i.e., $Z=6$ ), while the $\beta$-norsethite unit cell just contains 6 cationic layers and 6 carbonate layers (i.e., $Z=3$ ). Prior to the geometric optimization, the symmetry of both structures was set to the $P 1$ SG and no further symmetry constraints were imposed.

From the two norsethite structures described above, we have chosen $\beta$-norsethite to simulate different cation ordering arrangements. The reason for this choice is that for simulations of the $\beta$-norsethite structure computational times can be significantly reduced due to the lower number of atoms within its unit cell compared to $\alpha$-norsethite. Nevertheless, considering the slight differences between the structures of $\alpha$-norsethite and $\beta$-norsethite, the main results of the simulations of the $\beta$-norsethite structure can also be considered valid for $\alpha$-norsethite.

3.2. Interlayer Cation Disorder in the $\beta$-Norsethite Structure. Once the $\beta$-norsethite structure was optimized, different cationic configurations were studied by modifying 


a-norsethite $\mid \begin{array}{ccc}\mathrm{O}-\mathrm{C}-\mathrm{O} & & \\ \mathrm{Mg} & 6 \text {-fold } & 2 \\ \mathrm{O}-\mathrm{C}-\mathrm{O} & & \\ \mathrm{Ba} & 12 \text {-fold } & 1 \\ \mathrm{O}-\mathrm{C}-\mathrm{O} & & \\ \mathrm{Mg} & 6 \text {-fold } & 2 \\ \mathrm{O}-\mathrm{C}-\mathrm{O} & & \\ \mathrm{Ba} & 12 \text {-fold } & 1 \\ \mathrm{O}-\mathrm{C}-\mathrm{O} & & \\ \mathrm{Mg} & 6 \text {-fold } & 2 \\ \mathrm{O}-\mathrm{C}-\mathrm{O} & & \\ \mathrm{Ba} & 12 \text {-fold } & 1 \\ \mathrm{O}-\mathrm{C}-\mathrm{O} & & \\ \mathrm{Mg} & & \\ \mathrm{O}-\mathrm{C}-\mathrm{O} & \\ \mathrm{Ba} & \\ \mathrm{O}-\mathrm{C}-\mathrm{O} & \\ \mathrm{Mg} & \\ \mathrm{O}-\mathrm{C}-\mathrm{O} & \beta \text {-norsethite } \\ \mathrm{Ba} & \\ \mathrm{O}-\mathrm{C}-\mathrm{O} & \\ \mathrm{Mg} & \\ \mathrm{O}-\mathrm{C}-\mathrm{O} & \\ \mathrm{Ba} & \\ & \end{array}$

Figure 1. Scheme of the unit cell structure of $\alpha$-norsethite, all of the scheme (left line), and $\beta$-norsethite, half of the scheme (right line). The numbers 1 and 2 placed in the upper right part indicate 12 -fold and 6-fold coordinated positions, respectively. $\mathrm{Ba}$ denotes barium cations, $\mathrm{Mg}$ denotes magnesium cations, and $\mathrm{O}-\mathrm{C}-\mathrm{O}$ denotes the carbonate layers.

the stacking sequence of barium and magnesium layers, i.e., the interlayer cation disorder. The following $\beta$-norsethite structural configurations with different cation layer stacking sequences were generated:

Nor1: Ba1-Mg2-Ba1-Mg2-Ba1-Mg2 (i.e., fully ordered $\beta$-norsethite structure, Figure 1)

Nor2: $\mathrm{Ba} 1-\mathrm{Ba} 2-\mathrm{Ba} 1-\mathrm{Mg} 2-\mathrm{Mg} 1-\mathrm{Mg} 2$

Nor3: $\mathrm{Ba} 1-\mathrm{Ba} 2-\mathrm{Mg} 1-\mathrm{Ba} 2-\mathrm{Mg} 1-\mathrm{Mg} 2$

Nor4: $\mathrm{Ba} 1-\mathrm{Ba} 2-\mathrm{Mg} 1-\mathrm{Mg} 2-\mathrm{Ba} 1-\mathrm{Mg} 2$
Nor5: $\mathrm{Ba} 1-\mathrm{Mg} 2-\mathrm{Mg} 1-\mathrm{Ba} 2-\mathrm{Ba} 1-\mathrm{Mg} 2$

Nor6: $\mathrm{Mg} 1-\mathrm{Ba} 2-\mathrm{Mg} 1-\mathrm{Ba} 2-\mathrm{Mg} 1-\mathrm{Ba} 2$

Nor7: $\mathrm{Ba} 2-\mathrm{Mg} 1-\mathrm{Ba} 2-\mathrm{Mg} 1-\mathrm{Ba} 2-\mathrm{Mg} 1$

It is important to remark that while in the Nor6 configuration $\mathrm{Mg}$ cations were replaced by $\mathrm{Ba}$ cations and vice versa, in the Nor7 configuration, no cation substitution was conducted from Nor1, and the carbonate groups were rotated $60^{\circ}$ around the $c$-axis to change barium to a 6 -fold coordination and magnesium to a 12 -fold coordination.

3.3. Intralayer Cation Disorder in the $\beta$-Norsethite Structure. In nature, the cation disorder can also occur within a single cation layer, i.e., the intralayer cation disorder. To calculate the disorder degree in stoichiometric norsethite and other double carbonates, the following expression can be used: ${ }^{30,31}$

$$
s=2 X_{\mathrm{Mg}}-1
$$

where $X_{\mathrm{Mg}}$ denotes the occupancy of the $\mathrm{Mg}^{2+}$ cation in $\mathrm{Mg}$ sites. According to eq $1, s=1$ for a completely ordered structure and $s=0$ for a completely disordered structure.

Norsethite structures with different degrees of intralayer disorders were simulated by building a $2 \times 2 \times 1$ supercell (SC) after the first optimization of starting the fully ordered norsethite $R \overline{3} m$ structure. In such structures, half of the barium cations in the $\mathrm{Ba}$ layer were substituted by magnesium cations and half of the magnesium cations in the $\mathrm{Mg}$ layers were substituted by barium cations. By doing this, four $\beta$-norsethite structures with different cationic arrangements were generated (Figure 2). Furthermore, the effect of the ordering defect of a single $\mathrm{Ba}-\mathrm{Mg}$ pair on the structure of $\beta$-norsethite (i.e., Nor1) was simulated in a $2 \times 2$ $\times 1 \mathrm{SC}$, which corresponds with an order degree of $s=0.83$ (configuration D1 not shown in Figure 2).

3.4. Nonstoichiometric $\boldsymbol{\beta}$-Norsethite Structure. In addition to the structural configurations shown in Figure 2, the effect of an excess of $\mathrm{Ba}$ and $\mathrm{Mg}$ cations in the $\beta$ norsethite structure was also simulated by building a $2 \times 2 \times$ $1 \mathrm{SC}$ after the first optimization of the $\beta$-norsethite structure. In such $\mathrm{SC}$, one $\mathrm{Ba}$ cation in the second barium layer was

\begin{tabular}{|c|c|c|c|c|c|c|c|c|c|c|}
\hline & \multicolumn{2}{|c|}{ Nor1 } & \multicolumn{2}{|c|}{$\underline{\text { V1 }}$} & \multicolumn{2}{|c|}{$\underline{\mathrm{V} 2}$} & \multicolumn{2}{|c|}{$\underline{\mathrm{V} 3}$} & \multicolumn{2}{|c|}{$\underline{\text { V4 }}$} \\
\hline & $\mathrm{O}-\mathrm{C}-\mathrm{O}$ & $\mathrm{O}-\mathrm{C}-\mathrm{O}$ & $\mathrm{O}-\mathrm{C}-\mathrm{O}$ & $\mathrm{O}-\mathrm{C}-\mathrm{O}$ & $\mathrm{O}-\mathrm{C}-\mathrm{O}$ & O-C-O & O-C-O & O-C-O & O-C-O & $\mathrm{O}-\mathrm{C}-\mathrm{O}$ \\
\hline \multirow{3}{*}{2} & $\mathrm{Mg}$ & $\mathrm{Mg}$ & $\mathrm{Ba}$ & $\mathrm{Mg}$ & $\mathrm{Mg}$ & $\mathrm{Ba}$ & $\mathrm{Mg}$ & $\mathrm{Ba}$ & $\mathrm{Ba}$ & $\mathrm{Mg}$ \\
\hline & $\mathrm{Mg}$ & $\mathrm{Mg}$ & $\mathrm{Mg}$ & $\mathrm{Ba}$ & $\mathrm{Ba}$ & $\mathrm{Mg}$ & $\mathrm{Mg}$ & $\mathrm{Ba}$ & $\mathrm{Ba}$ & $\mathrm{Mg}$ \\
\hline & $\mathrm{O}-\mathrm{C}-\mathrm{O}$ & $\mathrm{O}-\mathrm{C}-\mathrm{O}$ & $\mathrm{O}-\mathrm{C}-\mathrm{O}$ & $\mathrm{O}-\mathrm{C}-\mathrm{O}$ & $\mathrm{O}-\mathrm{C}-\mathrm{O}$ & $\mathrm{O}-\mathrm{C}-\mathrm{O}$ & $\mathrm{O}-\mathrm{C}-\mathrm{O}$ & $\mathrm{O}-\mathrm{C}-\mathrm{O}$ & $\mathrm{O}-\mathrm{C}-\mathrm{O}$ & $\mathrm{O}-\mathrm{C}-\mathrm{O}$ \\
\hline \multirow{3}{*}{1} & $\mathrm{Ba}$ & $\mathrm{Ba}$ & $\mathrm{Ba}$ & Mg & $\mathrm{Ba}$ & Mg & $\mathrm{Ba}$ & $\mathrm{Mg}$ & $\mathrm{Ba}$ & Mg \\
\hline & $\mathrm{Ba}$ & $\mathrm{Ba}$ & Mg & $\mathrm{Ba}$ & Mg & $\mathrm{Ba}$ & $\mathrm{Ba}$ & Mg & $\mathrm{Ba}$ & Mg \\
\hline & $\mathrm{O}-\mathrm{C}-\mathrm{O}$ & $\mathrm{O}-\mathrm{C}-\mathrm{O}$ & $\mathrm{O}-\mathrm{C}-\mathrm{O}$ & $\mathrm{O}-\mathrm{C}-\mathrm{O}$ & $\mathrm{O}-\mathrm{C}-\mathrm{O}$ & $\mathrm{O}-\mathrm{C}-\mathrm{O}$ & $\mathrm{O}-\mathrm{C}-\mathrm{O}$ & $\mathrm{O}-\mathrm{C}-\mathrm{O}$ & $\mathrm{O}-\mathrm{C}-\mathrm{O}$ & $\mathrm{O}-\mathrm{C}-\mathrm{O}$ \\
\hline \multirow[t]{3}{*}{2} & $\mathrm{Mg}$ & $\mathrm{Mg}$ & $\mathrm{Ba}$ & $\mathrm{Mg}$ & $\mathrm{Mg}$ & $\mathrm{Ba}$ & $\mathrm{Mg}$ & $\mathrm{Ba}$ & $\mathrm{Ba}$ & $\mathrm{Mg}$ \\
\hline & $\mathrm{Mg}$ & $\mathrm{Mg}$ & $\mathrm{Mg}$ & $\mathrm{Ba}$ & $\mathrm{Ba}$ & $\mathrm{Mg}$ & $\mathrm{Mg}$ & $\mathrm{Ba}$ & $\mathrm{Ba}$ & $\mathrm{Mg}$ \\
\hline & $\mathrm{O}-\mathrm{C}-\mathrm{O}$ & $\mathrm{O}-\mathrm{C}-\mathrm{O}$ & $\mathrm{O}-\mathrm{C}-\mathrm{O}$ & $\mathrm{O}-\mathrm{C}-\mathrm{O}$ & $\mathrm{O}-\mathrm{C}-\mathrm{O}$ & $\mathrm{O}-\mathrm{C}-\mathrm{O}$ & $\mathrm{O}-\mathrm{C}-\mathrm{O}$ & $\mathrm{O}-\mathrm{C}-\mathrm{O}$ & $\mathrm{O}-\mathrm{C}-\mathrm{O}$ & $\mathrm{O}-\mathrm{C}-\mathrm{O}$ \\
\hline \multirow{3}{*}{1} & $\mathrm{Ba}$ & $\mathrm{Ba}$ & $\mathrm{Ba}$ & Mg & $\mathrm{Ba}$ & $\mathrm{Mg}$ & $\mathrm{Ba}$ & $\mathrm{Mg}$ & $\mathrm{Ba}$ & $\mathrm{Mg}$ \\
\hline & $\mathrm{Ba}$ & $\mathrm{Ba}$ & $\mathrm{Mg}$ & $\mathrm{Ba}$ & Mg & $\mathrm{Ba}$ & $\mathrm{Ba}$ & Mg & $\mathrm{Ba}$ & Mg \\
\hline & $\mathrm{O}-\mathrm{C}-\mathrm{O}$ & $\mathrm{O}-\mathrm{C}-\mathrm{O}$ & $\mathrm{O}-\mathrm{C}-\mathrm{O}$ & $\mathrm{O}-\mathrm{C}-\mathrm{O}$ & $\mathrm{O}-\mathrm{C}-\mathrm{O}$ & $\mathrm{O}-\mathrm{C}-\mathrm{O}$ & $\mathrm{O}-\mathrm{C}-\mathrm{O}$ & $\mathrm{O}-\mathrm{C}-\mathrm{O}$ & $\mathrm{O}-\mathrm{C}-\mathrm{O}$ & $\mathrm{O}-\mathrm{C}-\mathrm{O}$ \\
\hline \multirow{3}{*}{2} & $\mathrm{Mg}$ & $\mathrm{Mg}$ & $\mathrm{Ba}$ & $\mathrm{Mg}$ & $\mathrm{Mg}$ & $\mathrm{Ba}$ & $\mathrm{Mg}$ & $\mathrm{Ba}$ & $\mathrm{Ba}$ & $\mathrm{Mg}$ \\
\hline & $\mathrm{Mg}$ & $\mathrm{Mg}$ & $\mathrm{Mg}$ & $\mathrm{Ba}$ & $\mathrm{Ba}$ & $\mathrm{Mg}$ & $\mathrm{Mg}$ & $\mathrm{Ba}$ & $\mathrm{Ba}$ & $\mathrm{Mg}$ \\
\hline & $\mathrm{O}-\mathrm{C}-\mathrm{O}$ & $\mathrm{O}-\mathrm{C}-\mathrm{O}$ & $\mathrm{O}-\mathrm{C}-\mathrm{O}$ & $\mathrm{O}-\mathrm{C}-\mathrm{O}$ & $\mathrm{O}-\mathrm{C}-\mathrm{O}$ & $\mathrm{O}-\mathrm{C}-\mathrm{O}$ & $\mathrm{O}-\mathrm{C}-\mathrm{O}$ & $\mathrm{O}-\mathrm{C}-\mathrm{O}$ & $\mathrm{O}-\mathrm{C}-\mathrm{O}$ & $\mathrm{O}-\mathrm{C}-\mathrm{O}$ \\
\hline \multirow{2}{*}{1} & $\mathrm{Ba}$ & $\mathrm{Ba}$ & $\mathrm{Ba}$ & Mg & $\mathrm{Ba}$ & Mg & $\mathrm{Ba}$ & Mg & $\mathrm{Ba}$ & Mg \\
\hline & $\mathrm{Ba}$ & $\mathrm{Ba}$ & $\mathrm{Mg}$ & $\mathrm{Ba}$ & Mg & $\mathrm{Ba}$ & $\mathrm{Ba}$ & $\mathrm{Mg}$ & $\mathrm{Ba}$ & Mg \\
\hline
\end{tabular}

Figure 2. Scheme of ordered (Nor1) and four partially disordered intralayer cation arrangements of $\beta$-norsethite supercell (SC) structures before optimization (V1-V4). The numbers 1 and 2 placed in the left part indicate 12 -fold and 6-fold coordinated positions, respectively. Ba denotes barium cations, $\mathrm{Mg}$ denotes magnesium cations, and $\mathrm{O}-\mathrm{C}-\mathrm{O}$ denotes the carbonate layers. 
first substituted by one $\mathrm{Mg}$ cation to generate a $\beta$-norsethite structure with a $12.5 \%$ excess of magnesium. This slightly nonstoichiometric norsethite structure, named NorMg (Figure 3), has a composition similar to that of some

\begin{tabular}{|c|c|c|c|c|}
\hline & \multicolumn{2}{|c|}{ NorMg } & \multicolumn{2}{|c|}{ NorBa } \\
\hline \multirow{4}{*}{2} & $\mathrm{O}-\mathrm{C}-\mathrm{O}$ & $\mathrm{O}-\mathrm{C}-\mathrm{O}$ & $\mathrm{O}-\mathrm{C}-\mathrm{O}$ & $\mathrm{O}-\mathrm{C}-\mathrm{O}$ \\
\hline & $\mathrm{Mg}$ & $\mathrm{Mg}$ & $\mathrm{Mg}$ & $\mathrm{Mg}$ \\
\hline & $\mathrm{Mg}$ & $\mathrm{Mg}$ & $\mathrm{Mg}$ & $\mathrm{Mg}$ \\
\hline & $\mathrm{O}-\mathrm{C}-\mathrm{O}$ & $\mathrm{O}-\mathrm{C}-\mathrm{O}$ & $\mathrm{O}-\mathrm{C}-\mathrm{O}$ & $\mathrm{O}-\mathrm{C}-\mathrm{O}$ \\
\hline \multirow{3}{*}{1} & $\mathrm{Ba}$ & $\mathrm{Ba}$ & $\mathrm{Ba}$ & $\mathrm{Ba}$ \\
\hline & $\mathrm{Ba}$ & $\mathrm{Ba}$ & $\mathrm{Ba}$ & $\mathrm{Ba}$ \\
\hline & $\mathrm{O}-\mathrm{C}-\mathrm{O}$ & $\mathrm{O}-\mathrm{C}-\mathrm{O}$ & $\mathrm{O}-\mathrm{C}-\mathrm{O}$ & $\mathrm{O}-\mathrm{C}-\mathrm{O}$ \\
\hline \multirow{3}{*}{2} & $\mathrm{Mg}$ & $\mathrm{Mg}$ & $\mathrm{Mg}$ & $\mathrm{Mg}$ \\
\hline & $\mathrm{Mg}$ & $\mathrm{Mg}$ & $\mathrm{Mg}$ & $\underline{\mathrm{Ba}}$ \\
\hline & $\mathrm{O}-\mathrm{C}-\mathrm{O}$ & $\mathrm{O}-\mathrm{C}-\mathrm{O}$ & $\mathrm{O}-\mathrm{C}-\mathrm{O}$ & $\mathrm{O}-\mathrm{C}-\mathrm{O}$ \\
\hline \multirow{2}{*}{1} & $\mathrm{Ba}$ & $\mathrm{Ba}$ & $\mathrm{Ba}$ & $\mathrm{Ba}$ \\
\hline & $\mathrm{Ba}$ & $\underline{\mathrm{Mg}}$ & $\mathrm{Ba}$ & $\mathrm{Ba}$ \\
\hline \multirow{4}{*}{2} & $\mathrm{O}-\mathrm{C}-\mathrm{O}$ & $\overline{\mathrm{O}-\mathrm{C}-\mathrm{O}}$ & $\mathrm{O}-\mathrm{C}-\mathrm{O}$ & $\mathrm{O}-\mathrm{C}-\mathrm{O}$ \\
\hline & $\mathrm{Mg}$ & $\mathrm{Mg}$ & $\mathrm{Mg}$ & $\mathrm{Mg}$ \\
\hline & $\mathrm{Mg}$ & $\mathrm{Mg}$ & $\mathrm{Mg}$ & $\mathrm{Mg}$ \\
\hline & $\mathrm{O}-\mathrm{C}-\mathrm{O}$ & $\mathrm{O}-\mathrm{C}-\mathrm{O}$ & $\mathrm{O}-\mathrm{C}-\mathrm{O}$ & $\mathrm{O}-\mathrm{C}-\mathrm{O}$ \\
\hline \multirow[t]{2}{*}{1} & $\mathrm{Ba}$ & $\mathrm{Ba}$ & $\mathrm{Ba}$ & $\mathrm{Ba}$ \\
\hline & $\mathrm{Ba}$ & $\mathrm{Ba}$ & $\mathrm{Ba}$ & $\mathrm{Ba}$ \\
\hline
\end{tabular}

Figure 3. Scheme of NorMg and NorBa. Ba indicates barium cations and $\mathrm{Mg}$ indicates magnesium cations. In red and underlined are shown the cations added as an excess to the norsethite structure, and $\mathrm{O}-\mathrm{C}-\mathrm{O}$ indicates the carbonate layers. The numbers 1 and 2 located in the left part indicate 12-fold and 6-fold coordinated positions, respectively.

norsethites previously synthesized under ambient conditions, for which a $14 \%$ excess of magnesium was measured. ${ }^{32}$ Subsequently, a $\beta$-norsethite structure with an excess of barium (named NorBa) was simulated by substituting one $\mathrm{Mg}$ cation by one $\mathrm{Ba}$ cation in the central magnesium layer (Figure 3).

\section{RESULTS}

4.1. Structures of $\alpha$-Norsethite and $\beta$-Norsethite. The $\alpha$-norsethite and $\beta$-norsethite structures were fully optimized with CASTEP by relaxing atomic and crystal lattice structures (Figure 4). Then, the unit cell dimensions, bond lengths, and coordination numbers of both structures were determined (see Tables 1 and 2). We found that the parameters of the optimized structures are in good agreement with those experimentally determined ${ }^{14,16}$ and previously calculated. ${ }^{27,33}$ Only the $c$ parameter of $\alpha$-norsethite resulted to be about 2.3\% larger in our optimized structure than in that experimentally determined by Ende et al. ${ }^{16}$ To reduce such a slight discrepancy in the value of the $c$ parameter of norsethite, further calculations were conducted using other functional (RPBE and PBESOL) and pseudopotentials (OTFG norm conserving). However, the obtained results were not significantly different from the results shown in Table 1 (see Table S1). In the case of the $\beta$-norsethite structure, our calculated $a(=b)$ parameter was found to be only $0.014 \AA$ larger than that previously reported. ${ }^{14,16}$ Such a small difference in the $a$ parameter can be neglected and both theoretical and experimentally determined $\beta$-norsethite structures can be considered to be identical. In addition, taking into account that no symmetry constraints were imposed on the calculations performed, the obtained angles of the hexagonal crystal system (i.e., $\alpha=\beta=90^{\circ}$ and $\gamma=$ $\left.120^{\circ}\right)$, further support the validation of the calculation method used.

In Table 1, we can see that the $\mathrm{Mg}-\mathrm{O}$ bond lengths in our theoretical structure and experimentally determined $\alpha$-norsethite structure are similar. Comparatively, bonds between $\mathrm{Ba}$ and $\mathrm{O}$ atoms in the theoretical and experimental $\alpha$-norsethite structures have different lengths. Ende et al. described two barium polyhedra in the $\alpha$-norsethite structure, i.e., 12 -fold and 6-fold coordinated with the oxygen atoms. ${ }^{16}$ While the 6fold polyhedra are defined by six strong $\mathrm{Ba}-\mathrm{O}$ bonds $(2.790$ $\AA$ in length), the 12 -fold polyhedra are irregular polyhedra defined by these six strong bonds and another six weak bonds (3.097 $\AA$ in length). Although in our optimized $\alpha$-norsethite structure, the difference between the strong bonds $(2.757 \AA$ in length) and weak bonds (3.209 $\AA$ in length) is higher than in the experimental structures, we can still consider that the barium polyhedra are 12 -fold coordinated, i.e., defined by six strong and six weak bonds.

Differently, in the $\beta$-norsethite structure, the $\mathrm{Ba}-\mathrm{O}$ and $\mathrm{Mg}-\mathrm{O}$ bonds are almost identical in both the experimental and theoretical structures (Table 2). As a consequence, the $12 \mathrm{Ba}-\mathrm{O}$ bonds are all identical (2.95 $\AA$ in length) and, therefore, barium atoms are undoubtedly 12 -fold coordinated with oxygen atoms in the $\beta$-norsethite structure.

4.2. Interlayer Cation Disorder in the $\beta$-Norsethite Structure. In $\beta$-norsethite structures with different interlayer cation disorders, the most stable structural configurations are the most ordered ones, i.e., Nor1 and Nor7 (see Figure 5 and Table 3 ). In these configurations, $\mathrm{Ba}^{2+}$ cations occupy the 12 fold coordination $\mathrm{Ba}$ sites and $\mathrm{Mg}^{2+}$ cations occupy the 6-fold coordination $\mathrm{Mg}$ sites, in alternate stacking layers separated by carbonate groups. In another highly ordered configuration, Nor6, $\mathrm{Ba}^{2+}$ cations occupied the 6-fold coordinated $\mathrm{Mg}$ sites, and $\mathrm{Mg}^{2+}$ cations occupied the 12-fold coordinated $\mathrm{Ba}$ sites (Figure 5E). Although Nor1 and Nor6 structures might look identical, the Nor6 structure is the least energetically favorable due to the interchange of $\mathrm{Ba}$ and $\mathrm{Mg}$ sites, i.e., $\mathrm{Ba}^{2+}$ is 6-fold coordinated and $\mathrm{Mg}^{2+}$ is 12 -fold coordinated. Therefore, the Nor6 configuration is unlikely to be found in nature. Finally, the Nor7 configuration was built starting from Nor 1 and rotating the carbonate groups by $60^{\circ}$ around the caxis to coordinate $\mathrm{Mg}$ cations with 12 oxygen atoms and $\mathrm{Ba}$ cations with 6 oxygen atoms. With this rotation, the orientation of the $\mathrm{O}$ atoms with respect to cations is changed and, hence, the $\mathrm{Mg}$ coordination number changes to 12-fold and the Ba coordination number changes to 6-fold. However, after the optimization, the positions of oxygen atoms changed, and $\mathrm{Mg}$ and $\mathrm{Ba}$ cations become both 6-fold coordinated. The energy difference between Nor1 and Nor7 is very small and we can consider both of them as analogous and equally likely to be found, even though the value of $c$ is higher in Nor7 than in Nor1.

In all of these structural configurations, the interlayer cation disorder modified the cell parameters of $\beta$-norsethite, with $a$ and $b$ becoming shorter and $c$ larger than in the fully ordered structure and experimental structures (Table 3). Nevertheless, in all interlayer cation disordered structural configurations, the calculated $\alpha, \beta$, and $\gamma$ angles are in agreement with those characteristic of the hexagonal crystal system, i.e., $\alpha=\beta=90^{\circ}$ and $\gamma=120^{\circ}$. The energy differences of all configurations at $0 \mathrm{~K}$ with respect to Nor1 
A

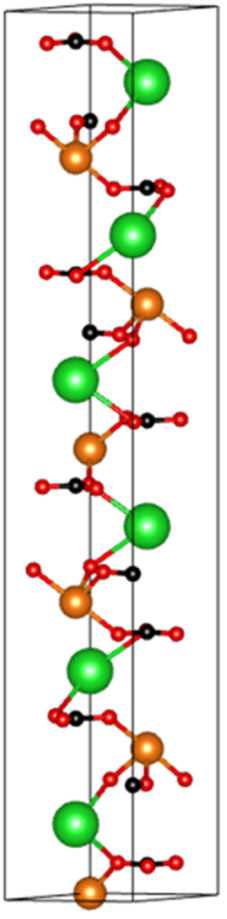

B

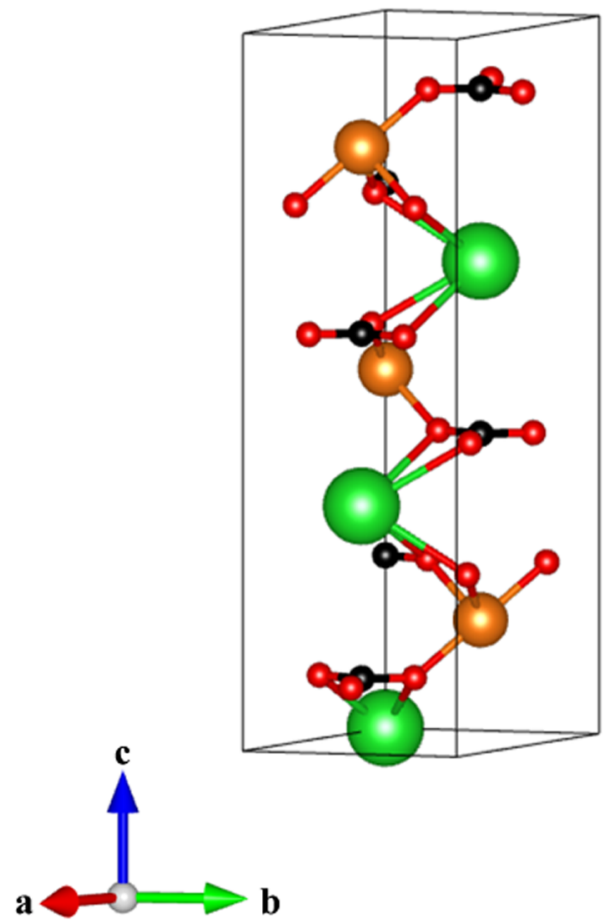

C

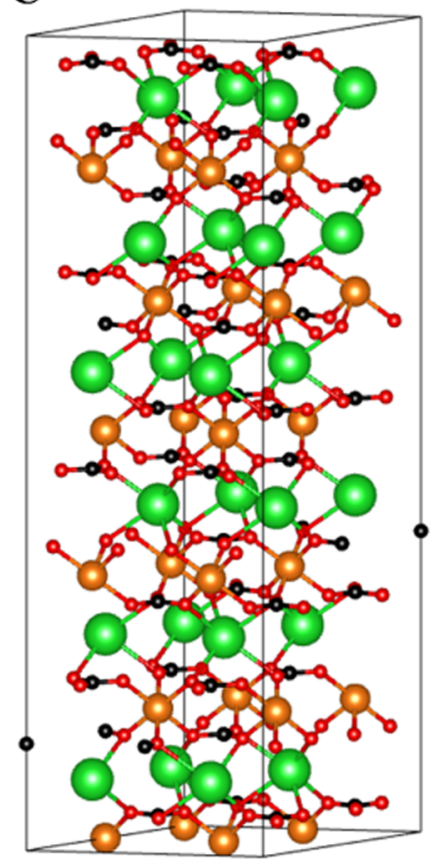

D

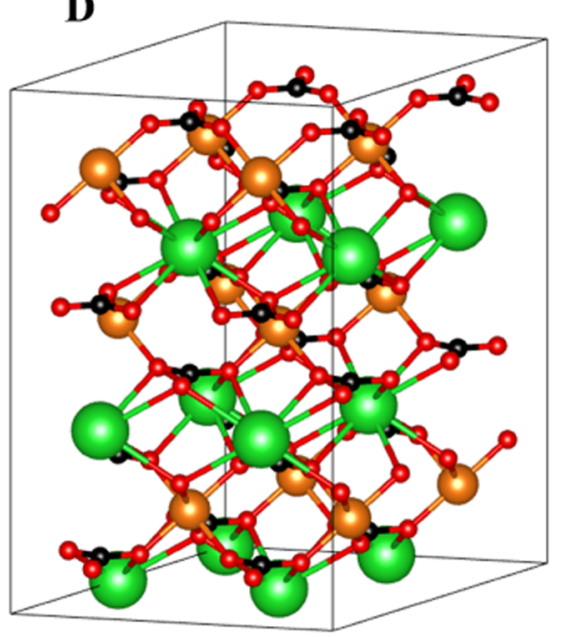

Figure 4. Optimized crystal structures of norsethite. (A) a unit cell of the $\alpha$-norsethite structure, (B) a unit cell of the $\beta$-norsethite structure. The supercells $2 \times 2 \times 1$ of $\alpha$-norsethite (C) and $\beta$-norsethite (D). Ba, $\mathrm{Mg}$, C, and $\mathrm{O}$ atoms are given in green, orange, black, and red colors, respectively. This color representation is extended to the rest of this work. Shared atoms in equivalent positions are not shown.

are not large, except for Nor6. This fact suggests that some of these disorder cation configurations might exist at room temperature due to entropic contributions. Moreover, these structural configurations with the interlayer cation disordered do not produce significant distortions in the carbonate groups. Only in the Nor2 configuration, the two carbonate groups lose the parallelism with the cation layers, and inclinations of $35^{\circ}$ with respect to the horizontal 00.1 plane were obtained.

Furthermore, another parameter that can be determined in carbonate minerals is the aplanarity of the carbonate groups, i.e., the distance between the carbon atom and the plane defined by the three oxygen atoms of the carbonate group. ${ }^{33}$ Remarkably, the different configurations of cation layers in the $\beta$-norsethite reduce the aplanarity of the carbonate groups 
Table 1. Parameters of the Fully Ordered $\alpha$-Norsethite Crystal Structure Calculated in This Work Compared With the Experimental Parameters Determined at $100 \mathrm{~K}$ by (a) Effenberger et al. ${ }^{15}$ and (b) Ende et al. ${ }^{16 a}$

\begin{tabular}{|c|c|c|c|}
\hline & $\begin{array}{c}(\mathrm{a}) \\
\text { experimental }\end{array}$ & $\begin{array}{c}(\mathrm{b}) \\
\text { experimental }\end{array}$ & theoretical (this work) \\
\hline$a(\AA)$ & 5.015 & 5.010 & 5.014 \\
\hline$b(\AA)$ & 5.015 & 5.010 & 5.014 \\
\hline$c(\AA)$ & 33.474 & 33.400 & 34.244 \\
\hline$\alpha(\operatorname{deg})$ & 90 & 90 & 90 \\
\hline$\beta(\mathrm{deg})$ & 90 & 90 & 90 \\
\hline$\gamma(\operatorname{deg})$ & 120 & 120 & 120 \\
\hline $\mathrm{Ba}-\mathrm{O}(\AA)$ & $2.796-3.102$ & $2.790-3.097$ & $2.757-3.209$ \\
\hline Ba (C.N.) & 12 & 12 & 12 \\
\hline $\mathrm{Mg}-\mathrm{O}(\AA)$ & 2.058 & 2.056 & 2.076 \\
\hline Mg (C.N.) & 6 & 6 & 6 \\
\hline
\end{tabular}

${ }^{a} \mathrm{C} . \mathrm{N}$. is the coordination number of the $\mathrm{Ba}-\mathrm{O}$ and $\mathrm{Mg}-\mathrm{O}$ polyhedra. Distances in $\AA$ between the atoms within these polyhedra are also given.

Table 2. Parameters of the Fully Ordered $\beta$-Norsethite Crystal Structure Calculated in This Work Compared With the Experimental Parameters Determined by (a) Effenberger et al. ${ }^{15}$ and (b) Ende et al., ${ }^{16}$ and Calculated by Winkler et al. ${ }^{33}$ (In Brackets) ${ }^{a}$

\begin{tabular}{lccl} 
& (a) experimental & (b) experimental & \multicolumn{1}{c}{ theoretical } \\
$a(\AA)$ & 5.022 & 5.021 & $5.035(5.061)$ \\
$b(\AA)$ & 5.022 & 5.021 & $5.035(5.061)$ \\
$c(\AA)$ & 16.77 & 16.75 & $16.754(17.676)$ \\
$\alpha(\mathrm{deg})$ & 90 & 90 & 90 \\
$\beta(\mathrm{deg})$ & 90 & 90 & 90 \\
$\gamma(\mathrm{deg})$ & 120 & 120 & 120 \\
$\mathrm{Ba}-\mathrm{O}(\AA)$ & 2.95 & 2.95 & 2.95 \\
$\mathrm{Ba}(\mathrm{C} . \mathrm{N})$. & 12 & 12 & 12 \\
$\mathrm{Mg}-\mathrm{O}(\AA)$ & 2.06 & 2.05 & 2.07 \\
$\mathrm{Mg}(\mathrm{C} . \mathrm{N})$. & 6 & 6 & 6
\end{tabular}

${ }^{a} \mathrm{C} . \mathrm{N}$. is the coordination number of the $\mathrm{Ba}-\mathrm{O}$ and $\mathrm{Mg}-\mathrm{O}$ polyhedra. Distances in $\AA$ between atoms within these polyhedra are also given.

(aplan in Table 3), Nor6 being the configuration with the lowest aplanarity.

4.3. Intralayer Cation Disorder in the $\beta$-Norsethite Structure. The intralayer cation disorder in the $\beta$-norsethite structure was simulated through the V1, V2, V3, and V4 configurations (see Figures 2 and 6). The fully ordered $\beta$ norsethite structure (i.e., Nor1) is the most stable one. For the $\beta$-norsethite structural configuration with the intralayer disorder, the energy is much higher than for structures with the interlayer disorder analyzed in Section 4.2. Hence, the structures from V1 to V4 are unlikely to be found in nature (Table 4). Although it may seem that the intralayer and interlayer cation disorders affect the $\beta$-norsethite structure in a similar way, the intralayer cation disorder has a major effect on this structure. For all of the configurations with the complete intralayer cation disorder $(s=0), a$ and $b$ parameters are shorter and $c$ is longer than those of the ordered structure (Table 4). In addition, in $\beta$-norsethite structures with intralayer cation disorder configurations, the parameters $a$ and $b$ are slightly different, varying between 0.1 and $0.5 \AA$ and the angles between the axes also differ from those corresponding to the hexagonal system (Table 4).
Comparatively, in $\beta$-norsethite structures with the interlayer cation disorder, the $a$ and $b$ parameters are closer to those of the experimental structures, and $\alpha$ and $\beta$ are $90^{\circ}$ and $\gamma$ is $120^{\circ}$.

The distortion in the unit cells in the different configurations is due to the various inclinations of the carbonate groups for accommodating the exchanged cations in the layers with 6-fold and 12-fold coordinations. The inclination of the carbonate group can be defined as the angle between the carbonate plane and the 00.1 plane. In these configurations, this angle varies from almost horizontal $\left(\sim 6^{\circ}\right)$ to almost vertical $\left(\sim 81^{\circ}\right)$, although the main values are in the $20-70^{\circ}$ range (Figure 6 ). In the case of the D1 structure, carbonate groups are almost horizontal, except around the cation substitution sites, where the carbonate groups have inclinations between 20 and $30^{\circ}$. This inclination of the carbonate groups can be clearly observed through the profiles of oxygen concentration along the [001] direction, as shown in Figures 7 and S2. In these profiles, the relative concentration of selected atoms, i.e., oxygen atoms, is plotted along the [001] direction. The narrow peaks with a high relative concentration indicate that all of the oxygen atoms of the carbonate layer are located at the same $z$ position. In turn, the peaks with low relative concentration values indicate that oxygen atoms of carbonate groups in the same carbonate layer are not located at the same $z$ position, i.e., the carbonate groups are not horizontal but tilted from the 00.1 plane. It is interesting to remark that, in these cation disordered structures, the loss of the horizontality of the carbonate groups reduces its aplanarity (Table 4).

Interestingly, some $\beta$-norsethite structural configurations can have a partial intralayer disordered arrangement, as in the configuration D1, without losing their symmetry (Table 4). In this slightly disordered $\beta$-norsethite structure, $\mathrm{Ba}^{2+}$ and $\mathrm{Mg}^{2+}$ cations are 12-fold and 6-fold coordinated respectively, except for $\mathrm{Ba}^{2+}$ cations in the $\mathrm{Mg}$ site, which is 6-fold coordinated, and $\mathrm{Mg}^{2+}$ cations in the $\mathrm{Ba}$ site, which is 10 -fold coordinated. This structure is $0.723 \mathrm{eV}$ less stable than the alternative ordered arrangement. This energy difference was calculated in static calculations at $0 \mathrm{~K}$. Hence, we can consider that the slight deviations from complete cation order as those shown by the configuration D1 are likely to form at room temperature.

4.4. Nonstoichiometric $\boldsymbol{\beta}$-Norsethite Structure. Considering that norsethite can exhibit deviations from stoichiometric composition, ${ }^{32}$ two different nonstoichiometric structures were studied: with an excess of magnesium, NorMg (Figure 8A), and with an excess of barium, NorBa (Figure $8 \mathrm{~B}$ ). As expected, given the larger size of the barium cations compared to magnesium cations, the crystal structure of NorBa is larger than the stoichiometric structure (Table 5). Accordingly, the crystal structure of NorMg is smaller than the stoichiometric structure (Table 5). Remarkably, in both cases, the cation substitution does not produce any significant distortion in the norsethite structure.

\section{DISCUSSION}

Our theoretical approach has shown that both $\alpha$-norsethite and $\beta$-norsethite structures can be adequately reproduced using DFT calculations. In particular, calculations of the $\beta$ norsethite structure resulted in the structural geometry and crystal dimensions closer to the previous experimental data $^{15,16}$ and theoretical calculations ${ }^{27,33}$ (Table 2). However, 

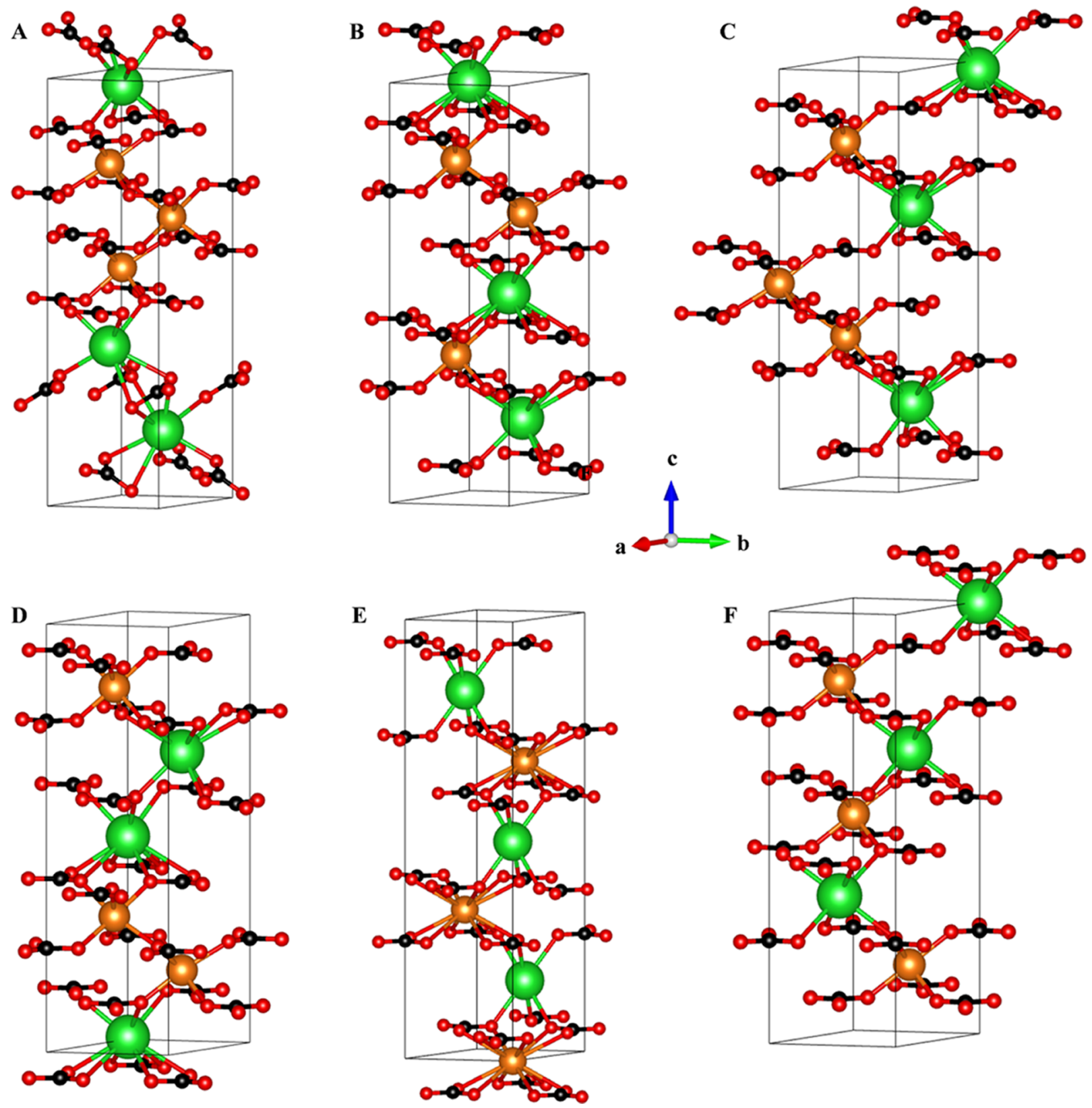

Figure 5. Models of cation layer configurations in the $\beta$-norsethite structure after optimization. (A) Nor2: $\mathrm{Ba} 1-\mathrm{Ba} 2-\mathrm{Ba} 1-\mathrm{Mg} 2-\mathrm{Mg} 1-\mathrm{Mg} 2$, (B) Nor3: Ba1-Ba2-Mg1-Ba2-Mg1-Mg2, (C) Nor4: Ba1-Ba2-Mg1-Mg2-Ba1-Mg2, (D) Nor5: Ba1-Mg2-Mg1-Ba2-Ba1-Mg2, (E) Nor6: $\mathrm{Mg} 1-\mathrm{Ba} 2-\mathrm{Mg} 1-\mathrm{Ba} 2-\mathrm{Mg} 1-\mathrm{Ba} 2$, and (F) Nor7: $\mathrm{Ba} 2-\mathrm{Mg} 1-\mathrm{Ba} 2-\mathrm{Mg} 1-\mathrm{Ba} 2-\mathrm{Mg} 1$. Shared atoms in equivalent positions of barium and magnesium are not shown.

when the cation disorder is introduced in the simulations of $\beta$-norsethite, a number of calculated structures exhibit significant distortions of the structure, which cannot be identified as norsethite. These structural variants with a high degree of disorder might correspond to the protocrystalline precipitates detected in the previously reported synthesis experiments of norsethite at ambient conditions. ${ }^{12,21,22,32}$ The formation of such "disordered norsethite configurations" could occur in a scenario of nonclassical crystallization favored by the high supersaturation starting conditions in the experiments. $^{21,22,32,34}$ Presumably, a high ionic mobility within these disordered configurations eventually results in the formation of norsethite crystals with the most stable cation arrangement. Nevertheless, the small energy differences between most of the norsethite disordered configurations (see Table 3) indicate that certain ordering defects can persist in this mineral. Probably, this phenomenon could also occur in the case of the mineral dolomite $\left(\mathrm{CaMg}\left(\mathrm{CO}_{3}\right)_{2}\right)$. The calculated energy differences between $\beta$-norsethite configurations with interlayer disorder are much higher than the $0.074 \mathrm{eV}$ value reported for cation ordering in the dolomite structure. ${ }^{7}$ Furthermore, while $\mathrm{Ba}^{2+}$ and $\mathrm{Mg}^{2+}$ cations are, respectively, 12-fold and 6-fold coordinated with the oxygen atoms in $\beta$-norsethite, $\mathrm{Mg}$ and $\mathrm{Ca}$ cations are both 6 -fold coordinated in the dolomite structure. This seems to indicate that partially disordered interlayer defects will be less probable in $\beta$-norsethite than in dolomite.

Remarkably, among the $\beta$-norsethite configurations with the interlayer cation disorder, Nor7 has a lower energy than that of the fully ordered configuration Norl. This would 
Table 3. Calculated Parameters of $\boldsymbol{\beta}$-Norsethite With Different Cation Layer Configurations ${ }^{a}$

\begin{tabular}{|c|c|c|c|c|c|c|c|}
\hline & Nor1 & Nor2 & Nor3 & Nor4 & Nor5 & Nor6 & Nor7 \\
\hline$a(\AA)$ & 5.035 & 4.845 & 4.987 & 4.987 & 4.989 & 5.010 & 5.022 \\
\hline$b(\AA)$ & 5.035 & 4.840 & 4.988 & 4.988 & 4.989 & 5.010 & 5.022 \\
\hline$c(\AA)$ & 16.754 & 18.415 & 17.383 & 17.383 & 17.353 & 20.209 & 17.057 \\
\hline $\operatorname{vol}\left(\AA^{3}\right)$ & 367.822 & 374.630 & 374.823 & 374.535 & 374.101 & 439.329 & 372.585 \\
\hline$\alpha(\operatorname{deg})$ & 90.0 & 90.0 & 90.0 & 90.0 & 90.0 & 90.0 & 90.0 \\
\hline$\beta(\operatorname{deg})$ & 90.0 & 90.1 & 90.0 & 90.0 & 90.0 & 90.0 & 90.0 \\
\hline$\gamma(\operatorname{deg})$ & 120.0 & 119.8 & 120.0 & 120.0 & 120.0 & 120.0 & 120.0 \\
\hline $\mathrm{Ba}-\mathrm{O}(\AA)$ & 2.95 & $2.78 \pm 0.11$ & $2.88 \pm 0.18$ & $2.86 \pm 0.70$ & $2.83 \pm 0.77$ & 2.60 & $2.78 \pm 0.01$ \\
\hline Ba (C.N.) & 12 & 8 & 9 & 9 & 9 & 6 & 6 \\
\hline $\mathrm{Mg}-\mathrm{O}(\AA)$ & 2.07 & $2.11 \pm 0.05$ & $2.13 \pm 0.07$ & $2.11 \pm 0.07$ & $2.11 \pm 0.07$ & 2.84 & 2.08 \\
\hline Mg (C.N.) & 6 & 6 & 6 & 6 & 6 & 12 & 6 \\
\hline $\mathrm{C}-\mathrm{O}(\AA)$ & 1.29 & $1.29 \pm 0.01$ & $1.30 \pm 0.01$ & $1.30 \pm 0.01$ & $1.30 \pm 0.01$ & 1.29 & 1.30 \\
\hline aplan $(\AA)$ & $0.038 \pm 0.000$ & $0.013 \pm 0.017$ & $0.025 \pm 0.018$ & $0.025 \pm 0.018$ & $0.025 \pm 0.018$ & $0.001 \pm 0.000$ & $0.035 \pm 0.000$ \\
\hline$E(\mathrm{eV})$ & 0.0 & 0.601 & 0.434 & 0.433 & 0.431 & 14.892 & -0.080 \\
\hline
\end{tabular}

${ }^{a} \mathrm{Vol}$ is the unit cell volume, C.N. is the coordination number of the $\mathrm{Ba}-\mathrm{O}$ and $\mathrm{Mg}-\mathrm{O}$ polyhedra, aplan is the aplanarity of the carbonate group (see explanation in the main text), and $E$ is the relative energy of the unit cell referred to the Norl configuration.

A

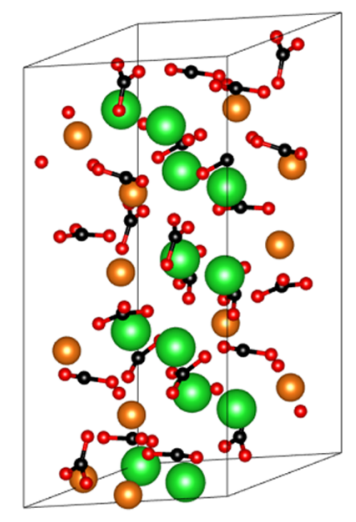

C

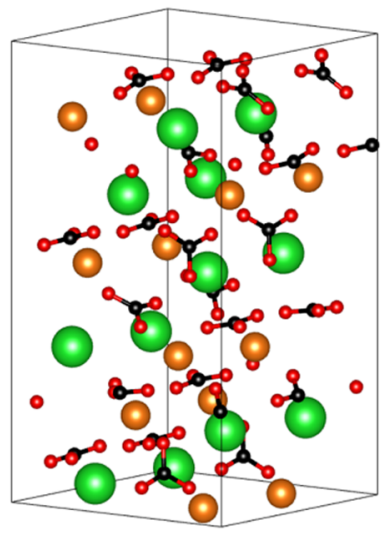

B

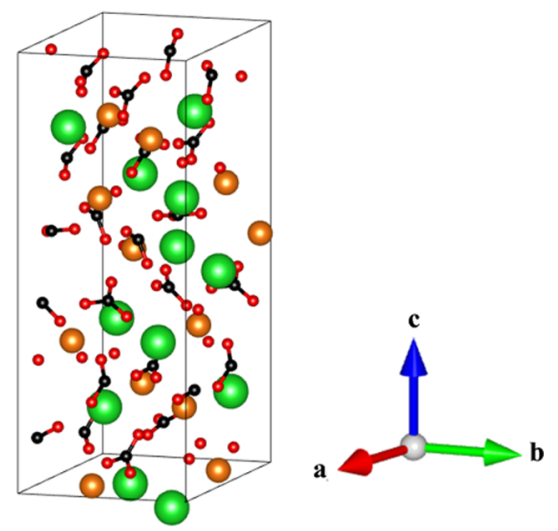

D

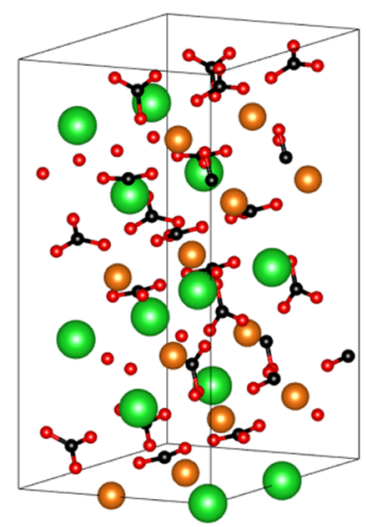

Figure 6. Models of the disordered intralayer cation arrangements of $\beta$-norsethite supercell $2 \times 2 \times 1$ (SC) structures after optimization: V1 (A), V2 (B), V3 (C), and V4 (D). Ba-O and $\mathrm{Mg}-\mathrm{O}$ bonds and shared atoms in equivalent positions were removed from the figure to facilitate the visualization of the cation disorder in the structure.

suggest that Nor7 is the most stable structural configuration of $\beta$-norsethite. To further analyze the similarities and differences between the theoretical and experimental structures, we calculated XRD patterns for $\beta$-norsethite and $\alpha$-norsethite. A first comparison shows that the XRD pattern of Nor7 is more similar to that of $\alpha$-norsethite than that of $\beta$ norsethite (see Figure 9). Therefore, the Nor7 structure is not a $\beta$-norsethite structure, in contrast, it can be considered as the $\alpha$-norsethite structure when building a $1 \times 1 \times 2$ supercell. This means that a slight rotation of carbonate groups with respect to the surrounding cations seems to be enough to induce a polymorphic phase transition from $\alpha$ - to $\beta$-norsethite. Since the energy difference between the norsethite polymorphs is small, the metastable crystallization of $\beta$-norsethite with a certain degree of disorder might occur at ambient conditions. Moreover, this small energy difference between $\alpha$-norsethite and $\beta$-norsethite is in good agreement with the differential scanning calorimetry (DSC) results obtained by the Effenberger et al. ${ }^{15}$ Nevertheless, these authors reported that the phase transition between the low- 
Table 4. Calculated Unit Cell Parameters of Ordered $\beta$-Norsethite, Those With Different Fully Disordered Cation Arrangements and Slightly Disordered $\beta$-Norsethite D1 $(s=0.83)^{a}$

\begin{tabular}{|c|c|c|c|c|c|c|}
\hline & Nor1 & $\mathrm{V} 1$ & $\mathrm{~V} 2$ & V3 & V4 & D1 $(s=0.83)$ \\
\hline$a(\AA)$ & 5.035 & 4.501 & 4.194 & 4.935 & 4.951 & 4.986 \\
\hline$b(\AA)$ & 5.035 & 4.637 & 4.350 & 4.627 & 4.501 & 4.991 \\
\hline$c(\AA)$ & 16.754 & 20.185 & 22.801 & 20.241 & 20.186 & 17.440 \\
\hline $\operatorname{vol}\left(\AA^{3}\right)$ & 367.822 & 381.839 & 391.578 & 396.719 & 381.651 & 376.355 \\
\hline$\alpha(\operatorname{deg})$ & 90.0 & 84.5 & 90.6 & 94.0 & 92.1 & 90.0 \\
\hline$\beta(\operatorname{deg})$ & 90.0 & 92.0 & 94.6 & 88.8 & 93.3 & 87.9 \\
\hline$\gamma(\operatorname{deg})$ & 120.0 & 114.4 & 109.1 & 120.6 & 121.5 & 120.0 \\
\hline $\mathrm{Ba}-\mathrm{O}(\AA)$ & 2.95 & $2.85 \pm 0.15$ & $2.88 \pm 0.17$ & $2.87 \pm 0.17$ & $2.85 \pm 0.14$ & $2.87 \pm 0.15$ \\
\hline $\mathrm{Ba}$ (C.N.) & 12 & 9 & 9 & 9 & 9 & 12 \\
\hline $\mathrm{Mg}-\mathrm{O}(\AA)$ & 2.07 & $2.13 \pm 0.12$ & $2.06 \pm 0.06$ & $2.13 \pm 0.12$ & $2.16 \pm 0.13$ & $2.12 \pm 0.07$ \\
\hline $\mathrm{Mg}$ (C.N.) & 6 & 5 & 5 & 6 & 6 & 6 \\
\hline $\mathrm{C}-\mathrm{O}(\AA)$ & 1.29 & $1.30 \pm 0.02$ & $1.30 \pm 0.03$ & $1.30 \pm 0.02$ & $1.30 \pm 0.02$ & $1.30 \pm 0.02$ \\
\hline aplan ( $)$ & $0.038 \pm 0.000$ & $0.027 \pm 0.017$ & $0.024 \pm 0.011$ & $0.013 \pm 0.017$ & $0.028 \pm 0.018$ & $0.029 \pm 0.013$ \\
\hline$E(\mathrm{eV})$ & 0.0 & 1.892 & 1.804 & 2.757 & 1.929 & 0.723 \\
\hline
\end{tabular}

${ }^{a} \mathrm{Vol}$ indicates the unit cell volume, C.N. indicates the coordination number of the $\mathrm{Ba}-\mathrm{O}$ and $\mathrm{Mg}-\mathrm{O}$ polyhedra, aplan is the aplanarity of the carbonate group, and $E$ is the relative energy of the unit cell in reference to the Nor1 structure.

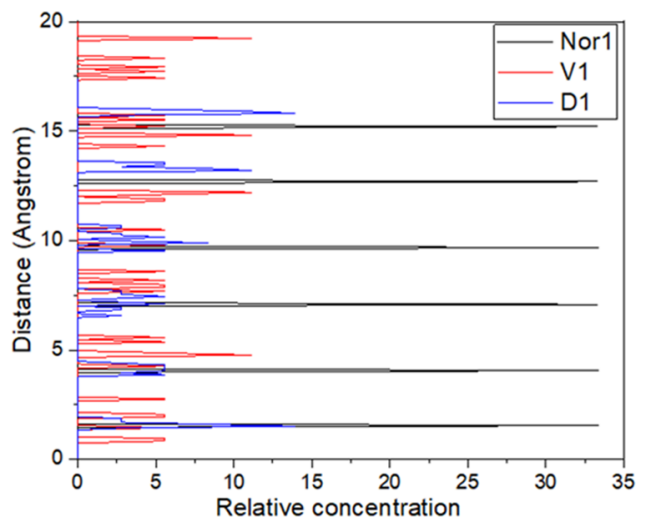

Figure 7. Concentration profile of oxygen atoms projected along the [001] direction of Nor1, V1, and D1 structures. A maximum relative concentration of 33 indicates that all of the oxygen atoms in the carbonate layer are coplanar, i.e., carbonate groups are parallel to the 00.1 plane. Peaks with a lower relative concentration indicate that carbonate groups have different angles to the 00.1 plane.
Table 5. Calculated Unit Cell Parameters of Ordered $\beta$ Norsethite and $\beta$-Norsethite With An Excess of $\mathrm{Mg}$ Cations (NorMg) and An Excess of Ba Cations (NorBa) ${ }^{a}$

\begin{tabular}{llll} 
& Nor1 & \multicolumn{1}{c}{ NorMg } & \multicolumn{1}{c}{ NorBa } \\
$a(\AA)$ & 5.035 & 5.023 & 5.052 \\
$b(\AA)$ & 5.035 & 5.023 & 5.052 \\
$c(\AA)$ & 16.754 & 16.671 & 17.151 \\
$\operatorname{vol}\left(\AA^{3}\right)$ & 367.822 & 364.322 & 379.187 \\
$\alpha(\mathrm{deg})$ & 90 & 90 & 90 \\
$\beta(\mathrm{deg})$ & 90 & 90 & 90 \\
$\gamma(\mathrm{deg})$ & 120 & 120 & 120 \\
$\mathrm{Ba}-\mathrm{O}(\AA)$ & 2.95 & $2.94 \pm 0.02$ & $2.93 \pm 0.13$ \\
$\mathrm{Ba}(\mathrm{C} . \mathrm{N})$. & 12 & 12 & 12 \\
$\mathrm{Mg}-\mathrm{O}(\AA)$ & 2.07 & $2.06 \pm 0.01$ & $2.07 \pm 0.03$ \\
$\mathrm{Mg}(\mathrm{C} . \mathrm{N})$. & 6 & 6 & 6 \\
\hline
\end{tabular}

${ }^{a} \mathrm{Vol}$ is the unit cell volume and C.N. is the coordination number of the $\mathrm{Ba}-\mathrm{O}$ and $\mathrm{Mg}-\mathrm{O}$ polyhedra.
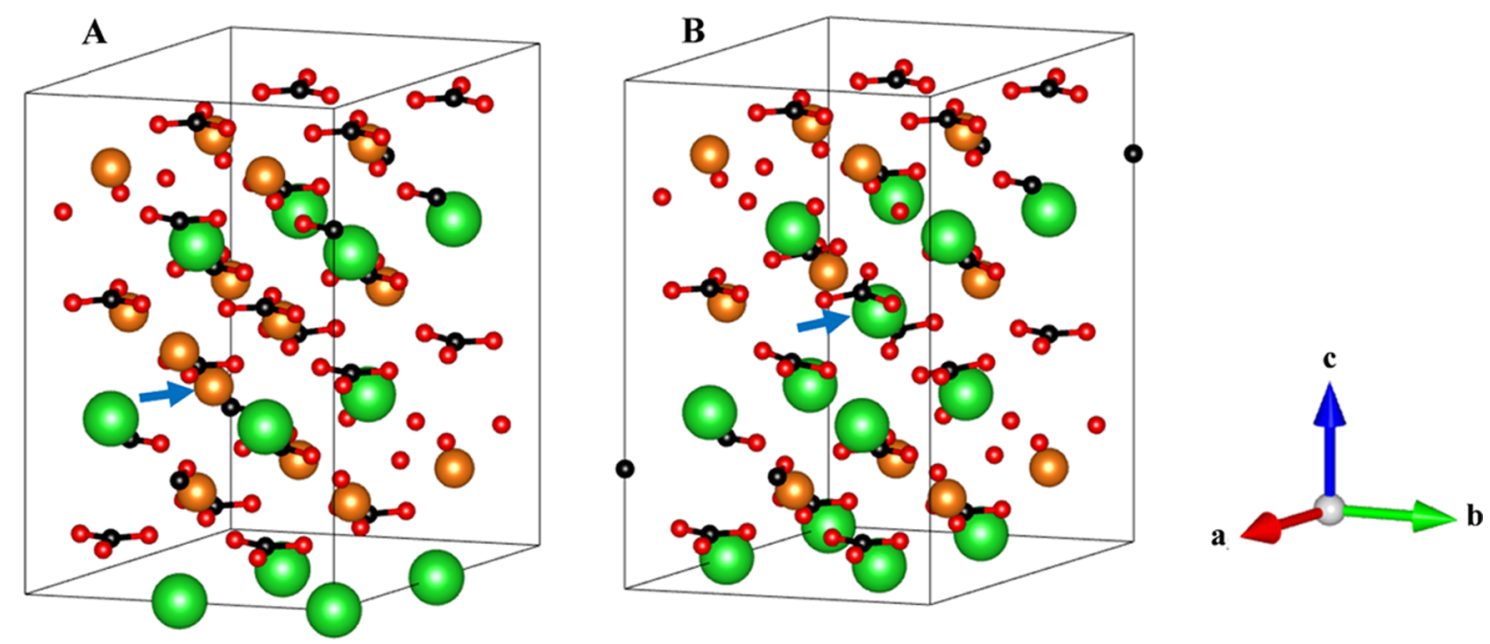

Figure 8. Models of $\beta$-norsethite SC structures with an excess of $\mathrm{Mg}(\mathrm{A})$ and $\mathrm{Ba}(\mathrm{B})$ after optimization. Substituted cations in both structures have been indicated by blue arrows. $\mathrm{Ba}-\mathrm{O}$ and $\mathrm{Mg}-\mathrm{O}$ bonds and shared atoms in equivalent positions were removed from the figure to facilitate the visualization of the cation disorder in the structure. 


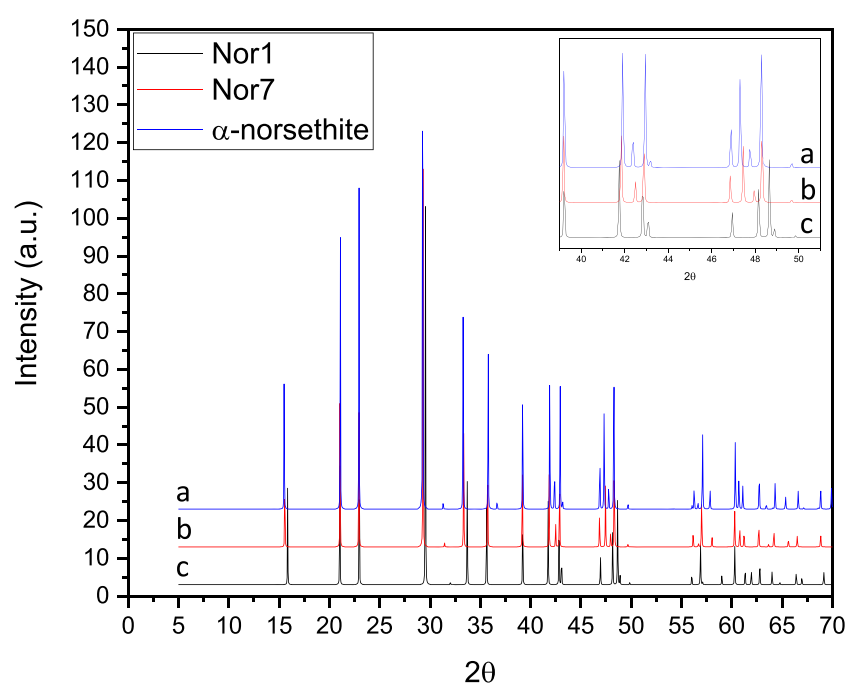

Figure 9. Simulated diffractograms of optimized norsethite structures: $\alpha$-norsethite (a, blue), $\beta$-norsethite (black, c, Nor1), and $\beta$-norsethite with carbonate groups rotated $60^{\circ}$ (red, b, Nor7). The inset shows the peaks between 40 and $50^{\circ}$, which allow us to determine that Nor7 is more similar to $\alpha$-norsethite than to $\beta$ norsethite (Nor1).

temperature and the high-temperature polymorphs is endothermic and reversible, and it involves a very low energy change.

The simulated XRD patterns of $\alpha$-norsethite and $\beta$ norsethite compared to the experimental diffractogram of an almost stoichiometric norsethite obtained at room temperature $^{21}$ are shown in Figure 10A. Although these diffractograms are very similar, an in-depth analysis shows that the diffraction peaks in the $2 \theta$ ranges of $40-45$ and $45-$ $50^{\circ}$ (see the inset of Figure 10A) are almost identical to those of the theoretical $\beta$-norsethite structure. This would indicate that norsethite crystals obtained by Pimentel and Pina are, in fact, crystals of $\beta$-norsethite. ${ }^{21}$ However, peaks in the experimental diffractogram are shifted to higher angles, i.e., the experimental norsethite structure has lower dspacings, compared to those in the fully ordered stoichiometric $\beta$-norsethite. Interestingly, this peak shifting can be strongly reduced by introducing $\mathrm{Mg}$ in the structure of $\beta$ norsethite. Thus, the experimental diffractogram shown in Figure $10 \mathrm{~B}$ is almost identical to that calculated for the simulated structure $\mathrm{NorMg}$, i.e., a $\beta$-norsethite structure with $12.5 \%$ excess of magnesium, in contrast with the semiquantitative results reported by Pimentel and Pina from energy dispersive X-ray (EDX) chemical analysis. ${ }^{21}$ These results indicate that a slight deviation from stoichiometry (i.e., $\mathrm{Mg} / \mathrm{Ba}>1$ ) favors the formation of metastable $\beta$ norsethite. However, further experimental and theoretical investigations are required to completely determine the stability/metastability relationship of nonstoichiometric $\beta$ and $\alpha$-norsethites at room temperature (i.e., $\mathrm{Mg} / \mathrm{Ba}$ ratios, supersaturation, solution $\mathrm{pH}$, etc.).

The results obtained in this work also provide some new insights into the formation of norsethite under ambient conditions. Pimentel and Pina ${ }^{21}$ have shown that an almost fully ordered norsethite is only formed after the dissolutionrecrystallization process from precursor phases (i.e., mainly amorphous barium and magnesium carbonates, witherite, and partially disordered norsethite). During this process, the $\mathrm{Ba}-$
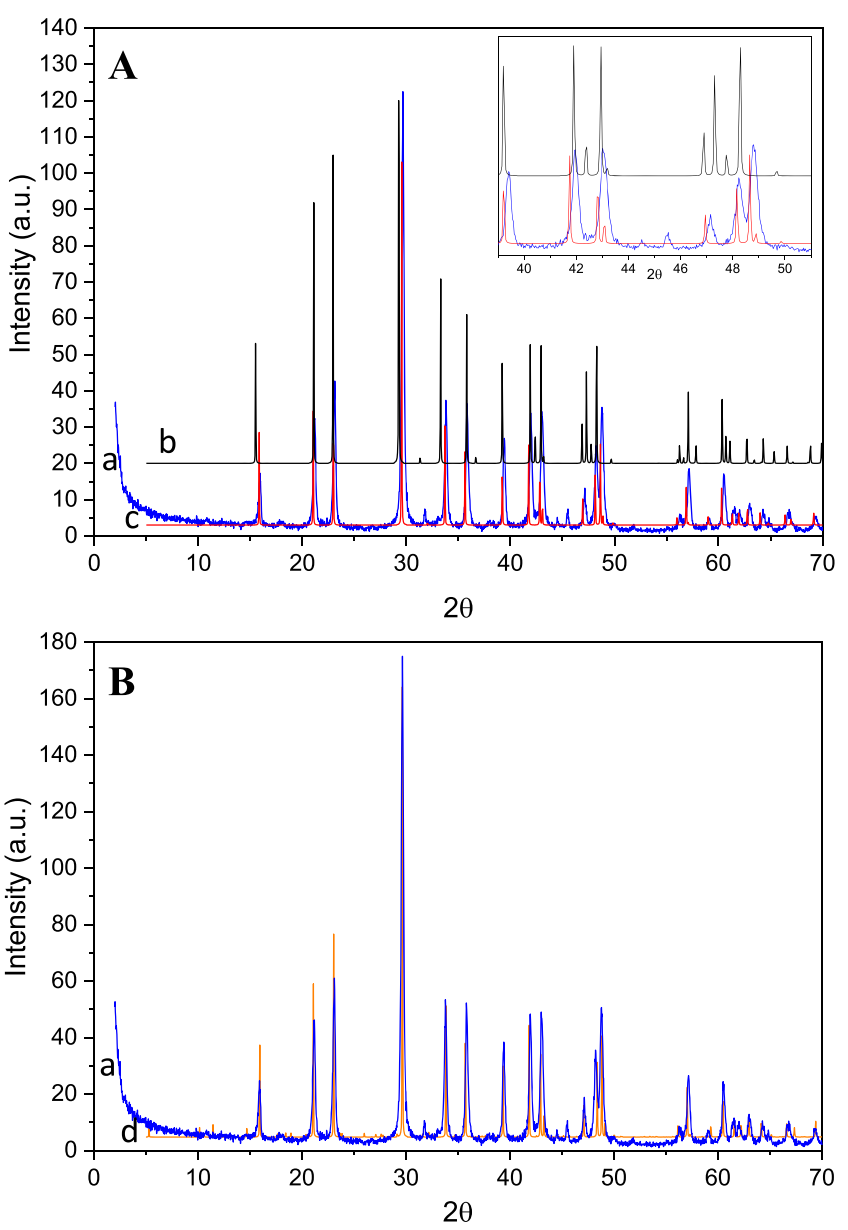

Figure 10. Experimental and simulated diffractograms of norsethite. (A) Comparison between the experimental norsethite ${ }^{21}$ (blue, a) and the optimized theoretically $\alpha$ and $\beta$ norsethites (black (b) and red (c), respectively). The inset shows the peaks between 40 and $50^{\circ}$, which allows the identification of the polymorph obtained by Pimentel and Pina at room temperature. ${ }^{21}$ (B) Comparison between the experimental norsethite (blue, a) and the optimized $\beta$-norsethite model NorMg (orange, d). Blue diffractogram adapted from Pimentel and Pina. ${ }^{21}$ Copyright 2014 Elsevier.

$\mathrm{Mg}$ order increases in the norsethite crystals progressively until it reaches a maximum value after $24 \mathrm{~h}$ of reaction. Interestingly, Pimentel and Pina did not detect the formation of a completely cation disordered norsethite as a starting phase. $^{21}$ This is supported by the calculations presented in this paper, which show that a completely disordered $\beta$ norsethite is not compatible with a hexagonal unit cell. Differently, norsethite structural configurations with a certain degree of $\mathrm{Ba}-\mathrm{Mg}$ ordering are theoretically possible and energetically more favorable than completely disordered norsethite structures. Furthermore, our calculations indicate that norsethite structural configurations with very low cationic order are probably very unstable. Nevertheless, at room temperature, some disordered configurations could exist due to entropic contributions. However, the existence of these disordered forms would be detected as additional XRD peaks, which are not observed experimentally. Hence, the number of these disordered configurations should be very low, and they could not be detected in the diffractograms as they quickly transform into norsethite with a higher degree of $\mathrm{Ba}-\mathrm{Mg}$ order. 
Once the cation order of norsethite and its crystallization mechanism have been discussed, it is of interest to briefly compare the norsethite and dolomite structures in relation to their formation process. Pimentel and Pina pointed out that the precipitation of norsethite at low temperatures might be favored over dolomite due to the lower structural constraints for the former. ${ }^{21,22}$ Accordingly, both the large radius of the $\mathrm{Ba}^{2+}$ cation and its high coordination number seem to provide to norsethite a wide structure that can easily accommodate the smaller $\mathrm{Mg}^{2+}$ cations during the crystallization process. Lindner and coauthors also invoked this idea to explain partly the results of their experiments on norsethite synthesis. $^{17-19}$

Except for Nor6 and Nor7, in all our simulated structural configurations of norsethite, $\mathrm{Ba}^{2+}$ cations have a higher coordination number than the $\mathrm{Mg}^{2+}$ cations. In addition, disordered structural configurations were found to have both a larger cell volume and a higher energy than those of the completely ordered norsethite structure. These results are consistent with the observed initial formation of almost stoichiometric norsethite with a certain degree of $\mathrm{Ba}-\mathrm{Mg}$ disorder, which rapidly evolves to highly ordered norsethite. ${ }^{21}$ In addition, these features, shared by most norsethite structural configurations, could also explain why norsethites with an excess of magnesium are easily synthesized at room temperature.

Although norsethite and dolomite minerals are analogues, their structural differences seem to play a role in their distinct formation pathways (i.e., in their crystallization kinetics). While in the dolomite structure, $\mathrm{Ca}^{2+}$ and $\mathrm{Mg}^{2+}$ coordination polyhedra are both 6 -fold, in the norsethite structure, $\mathrm{Ba}^{2+}$ has a higher coordination number (9-12 depending on the structural configurations) than $\mathrm{Mg}^{2+}(5-6)$. In addition, in the norsethite structure, $\mathrm{Ba}^{2+}$ sites are larger than those of $\mathrm{Ca}^{2+}$ and $\mathrm{Mg}^{2+}$ in the dolomite structure. Thus, we can expect that, under similar conditions, the process of nucleation and crystal growth of almost stoichiometric and slightly disordered norsethite from aqueous solutions is easier than the formation of poorly ordered dolomite crystals with $\mathrm{Mg} / \mathrm{Ca}$ ratios close to one. Furthermore, the wide structure of norsethite favors cationic mobility, and, therefore, a faster ordering process compared to that reported for the formation of fully ordered dolomite at ambient conditions. ${ }^{2-4}$ Nevertheless, further experimental and theoretical work is needed to better understand the role of structural constraints in the formation of dolomite and its analogues.

\section{CONCLUSIONS}

In this paper, both $\alpha$ - and $\beta$-norsethite crystal structures were calculated by quantum mechanical approximations. The DFT simulations have provided results in good agreement with previous experimental and theoretical works. Moreover, several interlayer and intralayer cation disordered configurations of the $\beta$-norsethite structure were simulated and analyzed. While the interlayer cation disorder resulted to be not representative of the cation disordered arrangements found in norsethite (and evidenced by experimentally obtained diffractograms and structures), the significant structural distortions produced by the intralayer cation might explain why the formation of $\beta$-norsethite without cationic ordering, i.e., with $s=0$, has not been reported to date. Moreover, in all of the disordering cases, $\mathrm{Ba}^{2+}$ cations were found to be 9-fold coordinated, while the coordination of $\mathrm{Mg}^{2+}$ cations was 5-fold or 6-fold, depending on the $\mathrm{Ba}-$ $\mathrm{Mg}$ configurations. Our simulations indicate that the lower energy of cation disordered structural configurations, together with their larger volume compared to that of the fully ordered structure, could favor the crystallization of $\beta$ norsethite with a certain degree of cation order prior to the formation of a fully ordered structure.

Finally, our calculations have been able to reproduce experimental diffractograms and structures of norsethites with a slight excess of $\mathrm{Mg}^{2+}$, i.e., norsethites with $\mathrm{Mg} / \mathrm{Ba}>1$. This computational work can be considered as a starting point for future experimental and theoretical studies, which further explore the conditions for crystallizing $\alpha$-norsethite or $\beta$ norsethite polymorphs with different degrees of stoichiometries and $\mathrm{Ba}-\mathrm{Mg}$ order.

\section{ASSOCIATED CONTENT}

\section{Supporting Information}

The Supporting Information is available free of charge at https://pubs.acs.org/doi/10.1021/acsearthspacechem.1c00058.

Single-point energy calculations to determine the best energy cut-off (Figure S1); crystal cell parameters of the stoichiometric ordered $\alpha$-norsethite, both experimental and theoretical, using different functionals and pseudopotentials (Table S1); concentration profiles of $\mathrm{Ba}, \mathrm{Mg}, \mathrm{C}$, and $\mathrm{O}$ along the [001] direction of Nor1, $\mathrm{D} 1, \mathrm{~V} 1, \mathrm{~V} 2, \mathrm{~V} 3$, and V4 (Figure S2) (PDF)

\section{AUTHOR INFORMATION}

\section{Corresponding Author}

Carlos Pimentel - Instituto Andaluz de Ciencias de la Tierra, Consejo Superior de Investigaciones Cientificas (CSIC)-Universidad de Granada, 18100 Granada, Spain; 이이이.org/0000-0002-5400-9102;

Email: c.pimentel@csic.es

\section{Authors}

Carlos M. Pina - Departamento de Mineralogía y Petrología, Facultad de Ciencias Geológicas, Universidad Complutense de Madrid, 28040 Madrid, Spain; Instituto de Geociencias (CSIC-UCM), 28040 Madrid, Spain; orcid.org/00000002-7748-5240

C. Ignacio Sainz-Díaz - Instituto Andaluz de Ciencias de la Tierra, Consejo Superior de Investigaciones Científicas (CSIC)—Universidad de Granada, 18100 Granada, Spain

Complete contact information is available at:

https://pubs.acs.org/10.1021/acsearthspacechem.1c00058

\section{Notes}

The authors declare no competing financial interest.

\section{ACKNOWLEDGMENTS}

The authors thank the Computational Center of CSIC for the high-performance computing service and Spanish projects FIS2016-77692-C2-2-P and PCIN-2017-098 for financial support. C.P. acknowledges Juan de la Cierva-Formación postdoctoral contract (Ref FJC2018-035820-I) from the Spanish Ministry of Science. The authors would also like to thank the three anonymous reviewers and Editor for their work in reviewing and handling this paper. 


\section{REFERENCES}

(1) Warren, J. Dolomite: occurrence, evolution and economically important associations. Earth-Sci. Rev. 2000, 52, 1-81.

(2) Kell-Duivestein, I. J.; Baldermann, A.; Mavromatis, V.; Dietzel, M. Controls of temperature, alkalinity and calcium carbonate reactant on the evolution of dolomite and magnesite stoichiometry and dolomite cation ordering degree - An experimental approach. Chem. Geol. 2019, 529, No. 119292.

(3) Pina, C. M.; Pimentel, C.; Crespo, A. Dolomite cation order in the geological record. Chem. Geol. 2020, 547, No. 119667.

(4) Zohdi, A.; Moallemi, S. A.; Moussavi-Harami, R.; Mahboubi, A.; Richter, D. K.; Geske, A.; Nickandish, A. A.; Immenhauser, A. Shallow burial dolomitization of an Eocene carbonate platform, southeast Zagros Basin, Iran. GeoArabia 2014, 19, 17-54.

(5) Ortega-Castro, J.; Hernández-Haro, N.; Dove, M. T.; Hernández-Laguna, A.; Sainz-Diaz, C. I. Density functional theory and Monte Carlo study of octahedral cation ordering of $\mathrm{Al} / \mathrm{Fe} / \mathrm{Mg}$ cations in dioctahedral 2:1 phyllosilicates. Am. Mineral. 2010, 95, 209-220.

(6) Sainz-Diaz, C. I.; Palin, E. J.; Hernández-Laguna, A.; Dove, M. $\mathrm{T}$. Octahedral cation ordering of illite and smectite. Theoretical exchange potential determination and Monte Carlo simulations. Phys. Chem. Miner. 2003, 30, 382-392.

(7) Zucchini, A.; Prencipe, M.; Comodi, P.; Frondini, F. Ab initio study of cation disorder in dolomite. Calphad 2012, 38, 177-184.

(8) Bruno, M.; Bittarello, E. Face of Ordered and Disordered Dolomite, $\mathrm{MgCa}(\mathrm{CO} 3) 2$ : A Computational Study to Reveal the Growth Mechanism. Minerals 2018, 8, No. 323.

(9) Bruno, M.; Ghignone, S.; Pastero, L.; Aquilano, D. The influence of $\mathrm{Ca}-\mathrm{Mg}$ disorder on the growth of dolomite: a computational study. CrystEngComm 2020, 22, 4853-4861.

(10) Hood, W. C.; Steidl, P. F.; Tschopp, D. G. Precipitation of Norsethite at Room Temperature. Am. Mineral. 1974, 59, 471-474.

(11) Lippmann, F. Sedimentary Carbonate Minerals; Springer: Berlin, 1973.

(12) Morrow, D. W.; Ricketts, B. D. Chemical controls on the precipitation of mineral analogues of dolomite: The sulfate enigma. Geology 1986, 14, 408-410.

(13) Mrose, M. E.; Chao, E.; Fahey, J.; Milton, C. Norsethite, $\mathrm{BaMg}\left(\mathrm{CO}_{3}\right)_{2}$, new mineral from Green River Formation, Wyoming. Am. Mineral. 1961, 46, 420-429.

(14) Effenberger, H.; Zemann, J. Single crystal X-ray investigation of norsethite, $\mathrm{BaMg}(\mathrm{CO} 3) 2$ : one more mineral with an aplanar carbonate group. Z. Kristallogr. - Cryst. Mater. 1985, 171, 275-280.

(15) Effenberger, H.; Pippinger, T.; Libowitzky, E.; Lengauer, C. L.; Miletich, R. Synthetic norsethite, $\mathrm{BaMg}(\mathrm{CO} 3) 2$ : revised crystal structure, thermal behaviour and displacive phase transition. Mineral. Mag. 2014, 78, 1589-1611.

(16) Ende, M.; Effenberger, H.; Miletich, R. Evolution of the $\alpha$ $\mathrm{BaMg}(\mathrm{CO} 3) 2$ low-temperature superstructure and the tricritical nature of its $\alpha-\beta$ phase transition. Acta Crystallogr., Sect. B 2017, 73, $827-835$.

(17) Lindner, M.; Jordan, G. On the growth of witherite and its replacement by the Mg-bearing double carbonate norsethite: Implications for the dolomite problem. Am. Mineral. 2018, 103, 252-259.

(18) Lindner, M.; Saldi, G. D.; Carrocci, S.; Bénézeth, P.; Schott, J.; Jordan, G. On the growth of anhydrous Mg-bearing carbonates Implications from norsethite growth kinetics. Geochim. Cosmochim. Acta 2018, 238, 424-437.

(19) Lindner, M.; Saldi, G. D.; Jordan, G.; Schott, J. On the effect of aqueous barium on magnesite growth - A new route for the precipitation of the ordered anhydrous Mg-bearing double carbonate norsethite. Chem. Geol. 2017, 460, 93-105.

(20) Liu, C.; Li, W. Transformation of amorphous precursor to crystalline carbonate: Insights from $\mathrm{Mg}$ isotopes in the dolomiteanalogue mineral norsethite $[\mathrm{BaMg}(\mathrm{CO} 3) 2]$. Geochim. Cosmochim. Acta 2020, 272, 1-20.
(21) Pimentel, C.; Pina, C. M. The formation of the dolomiteanalogue norsethite: Reaction pathway and cation ordering. Geochim. Cosmochim. Acta 2014, 142, 217-223.

(22) Pimentel, C.; Pina, C. M. Reaction pathways towards the formation of dolomite-analogues at ambient conditions. Geochim. Cosmochim. Acta 2016, 178, 259-267.

(23) Böttcher, M. E.; Gehlken, P.-L.; Reutel, C. The vibrational spectra of $\mathrm{PbMg}\left(\mathrm{CO}_{3}\right)_{2}$. Neues Jahrb. Mineral., Abh. 1996, 6, 241250.

(24) Böttcher, M. E.; Gehlken, P.-L.; Skogby, H.; Reutel, C. The vibrational spectra of $\mathrm{BaMg}\left(\mathrm{CO}_{3}\right)_{2}$ (norsethite). Mineral. Mag. 1997, 61, 249-256.

(25) Schmidt, B. C.; Gehlken, P.-L.; Böttcher, M. E. Vibrational spectra of $\mathrm{BaMn}\left(\mathrm{CO}_{3}\right)_{2}$ and a re-analysis of the Raman spectrum of $\mathrm{BaMg}\left(\mathrm{CO}_{3}\right)_{2}$. Eur. J. Mineral. 2013, 25, 137-144.

(26) Pippinger, T.; Miletich, R.; Effenberger, H.; Hofer, G.; Lotti, P.; Merlini, M. High-pressure polymorphism and structural transitions of norsethite, $\mathrm{BaMg}\left(\mathrm{CO}_{3}\right)_{2}$. Phys. Chem. Miner. 2014, $41,737-755$

(27) Zhuravlev, Y. N.; Atuchin, V. V. Comprehensive Density Functional Theory Studies of Vibrational Spectra of Carbonates. Nanomaterials 2020, 10, No. 2275.

(28) Tkatchenko, A.; Scheffler, M. Accurate Molecular Van Der Waals Interactions from Ground-State Electron Density and FreeAtom Reference Data. Phys. Rev. Lett. 2009, 102, No. 073005.

(29) Momma, K.; Izumi, F. VESTA 3 for three-dimensional visualization of crystal, volumetric and morphology data. J. Appl. Crystallogr. 2011, 44, 1272-1276.

(30) Helgeson, H. C.; Delany, J. M.; Nesbitt, H.; Bird, D. K. Summary and critique of the thermodynamic properties of rock forming minerals. Am. J. Sci. 1978, 278A, 1-129.

(31) Putnis, A. Introduction to Mineral Sciences; Cambridge University Press, 1992.

(32) Pimentel, C. Sintesis y Reactividad de Minerales del Grupo de la Dolomita y Fases Análogas. Ph.D. Thesis, Universidad Complutense de Madrid, 2017.

(33) Winkler, B.; Zemann, J.; Milman, V. Aplanarity of $\mathrm{CO}_{3}$ groups: a theoretical investigation. Acta Crystallogr., Sect. B 2000, 56, $648-653$.

(34) Cartwright, J. H. E.; Checa, A. G.; Gale, J. D.; Gebauer, D.; Sainz-Díaz, C. I. Calcium Carbonate Polyamorphism and Its Role in Biomineralization: How Many Amorphous Calcium Carbonates Are There? Angew. Chem., Int. Ed. 2012, 51, 11960-11970. 